\title{
An investigation into the effects of maternal supplementation with excess iodine on the mechanisms and impacts of reduced IgG absorption in the lamb postpartum
}

\author{
F. M. McGovern ${ }^{1,2}$, T. Sweeney ${ }^{2}$, M. T. Ryan ${ }^{2}$, S. Lott ${ }^{1}$, F. P. Campion ${ }^{1}$ and T. M. Boland ${ }^{1 *}$ \\ ${ }^{1}$ School of Agriculture and Food Science, Lyons Research Farm, University College Dublin (UCD), Newcastle, \\ Co. Kildare, W23 ENY2, Republic of Ireland \\ ${ }^{2}$ School of Veterinary Medicine, University College Dublin (UCD), Belfield, Co. Dublin, DO4 W6F6, Republic of Ireland \\ (Submitted 18 July 2016 - Final revision received 10 February 2017 - Accepted 17 February 2017-First published online 26 April 2017)
}

\section{Abstract}

An experiment was conducted to determine: (1) the effect of excess maternal I supplementation on the thyroid hormone status of the ewe and her progeny; (2) potential mechanisms underpinning the failure of passive transfer associated with excess I and (3) the growing lambs' response to natural gastrointestinal infection. Twin-bearing ewes received one of two treatments ( $n$ 32/treatment group): basal diet (C) or C plus $26.6 \mathrm{mg}$ of iodine/ewe per d (I), supplied as calcium iodate. Ewes were individually fed from day 119 of gestation to parturition. Progeny of I ewes had lower $(P<0 \cdot 01)$ serum IgG concentrations from $24 \mathrm{~h}$ to $28 \mathrm{~d}$ postpartum but higher serum IgG concentrations at day 70 postpartum $(P<0.05)$. I supplementation increased the relative expression of Fc receptor, IgA, IgM high affinity and polymeric Ig receptor in the ileum of the lamb at $24 \mathrm{~h}$ postpartum; however, thyroid hormone receptor- $\beta$ (THRB) and $\beta$-2-microglobulin (B2M) expression declined $(P<0.05)$. Progeny of I ewes had higher growth rates to weaning $(P<0.05)$ and lower faecal egg count (FEC) for Nematodirus battus $(P<0.05)$ between weeks 6 and 10 postpartum. In conclusion, excess maternal I supplementation negatively affected the thyroid hormone status, serum IgG concentration, ileal morphology and the gene expression of THRB and B2M in the ileum and ras-related protein (RAB) RAB25 and the mucin gene (MUC) MUC1 in the duodenum of the lamb postpartum. These effects were followed by an enhancement of average daily gain and lower $N$. battus FEC in the pre-weaning period of I-supplemented lambs.

\section{Key words: Ewes: Nutrition: Pregnancy: Colostrum IgG: Iodine}

Estimates of ovine pre-weaning mortality currently range from 10 to $30 \%$ wordwide, with the neonatal period being the most vulnerable in this regard ${ }^{(1)}$. Hypothermia, starvation and infectious disease have been identified as the major causes of mortality within the first $3 \mathrm{~d}$ of $\mathrm{life}^{(2)}$. With regard to infection, gastrointestinal nematodes (GIN) have been recognised as the most pervasive problem facing sheep production enterprises ${ }^{(3)}$. Of these, Nematodirus battus has been identified as one of the most prevalent parasites affecting animals in cool, temperate climates; with lambs susceptible to infection from 5 weeks of age $^{(4)}$. Subclinical infection with GIN results in significant production losses due to weight loss and reduced weight gain, particularly in young, naïve animals ${ }^{(3)}$. The hypo-immunocompetent nature of the newborn ruminant increases its reliance on acquiring passive immunity in early life ${ }^{(5,6)}$. Therefore, adequate colostrum consumption is critical to provide nutrition and promote Ig transfer; thus augmenting the ensuing health and survival of the neonatal $\operatorname{lamb}^{(7)}$. Ig are plasma proteins produced by lymphocytes in the mammalian bloodstream in response to foreign antigens. They are part of the innate immune system, which is the primary line of defense against pathogens and therefore are essential in the development of disease resistance ${ }^{(8)}$. Previous work has found that young lambs are capable of mounting a specific antibody response to $N$. battus, which has been associated with the majority of adult worms being rejected by $21 \mathrm{~d}$ post infection ${ }^{(9)}$. As IgG constitutes approximately $92 \%$ of Ig found in ovine colostrum ${ }^{(10)}$, it the most prevalent Ig class and provides adequate immunity to the neonatal lamb during the initial weeks of independent life ${ }^{(11)}$.

Previous work has outlined that excess I supplementation to ewes in late gestation alters the thyroid hormone status of the newborn lamb, which results in a failure to acquire passive immunity, evidenced by a reduced serum IgG concentration at 24 h postpartum $^{(6,12)}$. This has been shown to occur independently of colostrum intake and colostrum IgG concentration ${ }^{(13)}$ thus suggesting that there is an alteration in the functioning of

Abbreviations: B2M, $\beta$-2-microglobulin; BCS, body condition score; C, basal diet; CD, crypt depth; $\mathrm{CP}$, crude protein; FCRn, neonatal FC receptor; FEC, faecal egg count; FEC $_{\mathrm{N}}$, faecal egg count for Nematodirus battus; FPT, failure of passive transfer; I, C plus $26.6 \mathrm{mg}$ of I/ewe per d; ME, metabolisable energy; MUC, mucin genes; RAB, ras-related protein; $\mathrm{T}_{3}$, tri-iodothyronine; $\mathrm{T}_{4}$, thyroxine; $\mathrm{VH}$, villus height.

* Corresponding author: T. M. Boland, email tommy.boland@ucd.ie 
the lambs' intestinal absorptive process which occurs in utero. The primary site of IgG absorption in the newborn is the lower ileum $^{(14)}$; with a previous experiment identifying a link between excess maternal I supplementation and the failure of passive transfer (FPT) of $\operatorname{IgG}^{(13)}$. These authors concluded that FPT was mediated through the thyroid hormone status of the animal and influenced the expression of Ig-related genes in the intestinal tract immediately postpartum ${ }^{(12)}$.

Therefore, the objectives of this study were as follows: (1) to determine the effect of excess I supplementation to the pregnant ewe on the thyroid hormone status of both the ewe and her progeny at parturition; (2) to identify potential mechanisms responsible for FPT by examining the expression profiles of selected genes in the ileum, duodenum, thyroid and perirenal adipose tissue of the lamb at $24 \mathrm{~h}$ postpartum; and (3) to assess the effect of FPT on the growing lambs' response to gastrointestinal infection.

\section{Methods}

All procedures involving ewes and lambs in this study were conducted under experimental licence from the Irish Medicines Board in accordance with the European Union (protection of animals used for scientific purposes) regulations 2012 (S.I. No. 543 of 2012). This study was conducted at University College Dublin, Lyons Research Farm, Newcastle, Co. Dublin.

\section{Pre-experimental animal management}

Ewes were confirmed as pregnant and twin-bearing to a synchronised oestrus (intervaginal progestagen pessaries; Chronogest and Folligon, Intervet Ireland Ltd) followed by an intramuscular injection of $500 \mathrm{IU}(2.5 \mathrm{ml})$ pregnant mare serum gonadotropin (Chronogest and Folligon, Intervet Ireland Ltd), following a transabdominal ultrasound on day 77 post insemination (inseminated with fresh diluted semen, at a rate of 20 million spermatozoa per uterine horn, using laparoscopic artificial insemination (AI)). Before selection, the ewes were blocked on the basis of live weight $(75.5$ (SE 2.29) kg) and balanced for body condition score (BCS) (2.96 (sE 0.06)), age (3.4 (se 0.95) years), ewe breed and lamb-sire breed. BCS assessments were made by a trained technician and ewes were scored on a scale of $0-5^{(15)}$.

\section{Nutritional treatments}

On day 113 of gestation, ewes were allocated to one of two nutritional treatment groups and transferred to individual, wooden-slatted pens measuring $1.1 \times 1.4 \mathrm{~m}$. The animals were allowed a 7 -d adaption period before experimental feeding began on day 119 of gestation. All ewes were fed to meet $100 \%$ of predicted metabolisable energy (ME) requirements for mature, gestating twin-bearing ewes ${ }^{(16,17)}$. Ewes received either a basal diet (C), which included mineral and I supplementation or they received $C$ plus an additional daily allowance of $26.6 \mathrm{mg}$ of I supplied in the form of calcium iodate (I, $42.9 \mathrm{mg} /$ ewe per day; Devenish Nutrition). I inclusion levels were not confirmed analytically and are based on calculated formulation. This level of I equates to the level offered to ewes in a recently reported study ${ }^{(6)}$ and is reflective of the level of intake achieved when ewes are offered free access mineral supplements indoors $^{(18)}$.

\section{Feeding}

ME requirements, based on those outlined by the Agricultural and Food Research Council Technical Committee ${ }^{(16)}$ and including amendments ${ }^{(17)}$, were calculated individually for each ewe ${ }^{(19)}$. Silage was offered at 08.00 hours each morning following the removal of the previous days' silage refusals. The quantity of concentrate offered was calculated for each individual animal depending on the level of ME received from the silage and their individual ME allocation as per treatment group. Concentrates were offered daily at 09.00 hours or twice daily at 09.00 and 17.00 hours in equal allocations when daily allocation exceeded $500 \mathrm{~g}$ (fresh weight)/ewe. The iodine supplement was manually mixed into the concentrate on the day before feeding. Before mixing, the iodine allowance was first added to $20 \mathrm{~g}$ (fresh weight) of the concentrate that was used as a carrier for the supplement. Before the mineral inclusion, this carrier was dried using forced air circulation at $55^{\circ} \mathrm{C}$ for $72 \mathrm{~h}$, following which it was ground through a $0.8 \mathrm{~mm}$ screen using a Christy and Norris hammer mill (Christy Turner Ltd). The daily concentrate allowance was then adjusted to take into account the carrier contribution. Ewes received an $18 \%$ crude protein (CP) concentrate which comprised barley (40\%), soya hulls (29\%), whole-wheat distillers (25\%) and molasses (4\%), on a DM basis. In addition, the concentrate offered contained minerals (2\%) and cane molasses (2\%). The level of I in C was in excess of standard dietary requirements because of the inclusion of $\mathrm{I}$ in the mineral portion of $\mathrm{C}$. The chemical composition of the feedstuff offered is outlined in Table 1. Representative samples of both silage and concentrate were taken each morning and frozen at $-20^{\circ} \mathrm{C}$ for subsequent proximate analysis. Ewes had continuous access to clean, fresh drinking water at all times. Post lambing, all ewes were reverted to $\mathrm{C}$ and received grass silage ad libitum plus concentrates $(1 \mathrm{~kg})$, fed twice daily in equal allocations. At $3 \mathrm{~d}$ postpartum, all ewes were turned out onto a perennial rye-grass pasture and were rotationally grazed as a single group along

Table 1. Chemical composition of silage and concentrate offered to ewes during late gestation

\begin{tabular}{lcc}
\hline Compositions $(\mathrm{g} / \mathrm{kg})$ & Silage & $18 \%$ concentrate $^{*}$ \\
\hline DM & $232 \cdot 8$ & 759.4 \\
Crude protein & $140 \cdot 4$ & 176.8 \\
Neutral detergent fibre & $428 \cdot 8$ & 274.6 \\
Acid detergent fibre & 269.5 & 154.6 \\
Acid detergent lignin & $19 \cdot 0$ & - \\
Starch & - & $249 \cdot 7$ \\
Diethyl ether extract & 41.0 & $28 \cdot 8$ \\
Ash & 83.7 & 46.9 \\
Gross energy (MJ/kg) & 16.12 & $17 \cdot 1$ \\
Metabolisable energy (MJ/kg) & 10.0 & 12.03 \\
\hline
\end{tabular}

* Percentage of crude protein in the concentrate; $18 \%$ crude protein. 
with their lambs. At this stage, concentrate supplementation was discontinued.

\section{Ewe measurements and lambing data}

Ewes were assessed for BCS and weighed on an electronic scale (Prattley), with live weights recorded electronically (Tru-Test Group) on day 114 of gestation, 24 h, day 40 and 98 postpartum. A $10 \mathrm{ml}$ blood sample was collected from all ewes on day 119 of gestation (trial start date) and $24 \mathrm{~h}$ postpartum via jugular venepuncture using heparinised vacutainers (ref: 367 526; Becton, Dickinson and Company). Blood samples were immediately placed on ice and centrifuged at $4{ }^{\circ} \mathrm{C}$ and $1800 \mathrm{~g}$ for $15 \mathrm{~min}$ after which the plasma was pipetted into pour-off tubes and frozen at $-20^{\circ} \mathrm{C}$ until further analysis.

All ewes lambed down in their individual pens where they remained with their lambs until $72 \mathrm{~h}$ postpartum. Within the 1 st hour after parturition, the navel of each lamb was dipped in a $10 \%$ I (Ritchey) solution, to aid in the control of erysipelas polyarthritis (joint-ill), following which time of birth, birth weight, sex and the level of assistance required by the ewe at lambing (referred to hereafter as lambing difficulty; LD) were recorded for each lamb. LD was assessed, by trained observers, using a score between 1 and 4 where 1 referred to a natural unassisted lambing and 4 referred to a caesarean section. The time of birth of the first lamb was used to calculate the gestation length $(\mathrm{GL})$ of the ewe, with 12.00 hours on the day of AI taken as $0 \mathrm{~h}$. At $24 \mathrm{~h}$ postpartum all lambs were ear-tagged with an electronic identification tag. All incidences of erysipelas polyarthritis (joint-ill) and Escherichia coli were recorded in lambs from birth until day 14 postpartum. E. coli was diagnosed in lambs that presented with a watery mouth, a distended abdomen and showed obvious signs of pain, lack of appetite and isolation from the dam.

\section{Hand milking}

At parturition sixteen ewes per treatment group were randomly selected and an udder cover placed on them, until $24 \mathrm{~h}$ postpartum in order to prevent the lambs from suckling. Ewes were hand milked at 1,10 and $18 \mathrm{~h}$ postpartum as previously described $^{(18)}$. In brief, each ewe received an intramuscular injection of $10 \mathrm{IU}$ of oxytocin (Oxytocin-S; Intervet Ltd) immediately before each milking to ensure total milk let-down ${ }^{(20)}$. Ewes were milked out completely by hand and the total volume was recorded after each milking. From this, the total volume produced up to $18 \mathrm{~h}$ postpartum was calculated. For the determination of total solid (TS) and CP content, a colostrum sample $(25 \mathrm{ml})$ was taken at the $1 \mathrm{~h}$ milking and stored at $-20^{\circ} \mathrm{C}$ until required.

Following each milking, the lambs were fed measured quantities of colostrum from their dam via a stomach tube. Depending on the yield of colostrum, lambs received the maximum amount of colostrum available, within the range of $20-50 \mathrm{ml}$ colostrum per $\mathrm{kg}$ birth weight. The quantity of colostrum fed to each lamb was recorded.

\section{Lamb blood sample collection}

At $1 \mathrm{~h}$ postpartum, and before stomach tubing where appropriate, a $10 \mathrm{ml}$ plasma blood sample was collected via jugular venepuncture in heparinised vacutainers (BD; Ref: 367 880) from all lambs. The blood samples were immediately placed on ice and centrifuged at $4^{\circ} \mathrm{C}$ at $1800 \mathrm{~g}$ for $15 \mathrm{~min}$, after which, the plasma was pipetted into pour-off tubes and stored at $-20^{\circ} \mathrm{C}$ until further analysis. At $24 \mathrm{~h}$ postpartum (and before euthanasia where appropriate) and fortnightly thereafter until day 70 , a blood sample was collected via jugular venepuncture in nonheparinised vacutainers (BD; Ref: 368 975) from all lambs. Blood samples were stored at room temperature for $1 \mathrm{~h}$ before storage at $4^{\circ} \mathrm{C}$ where they remained for $24 \mathrm{~h}$. Samples were subsequently centrifuged at $4^{\circ} \mathrm{C}$ and $1800 \mathrm{~g}$ for $15 \mathrm{~min}$ to obtain the serum, which was then frozen at $-20^{\circ} \mathrm{C}$ until further analysis.

\section{Organ collection and small intestinal morphology}

At $24 \mathrm{~h}$ postpartum, a subgroup of twenty-four lambs ( $n$ 12/treatment group) were euthanised with Euthatal (pentobarbitone sodium BP; Merial Animal Health Limited) at a rate of $1 \mathrm{ml} / \mathrm{kg}$ body weight. This resulted in eighteen ewes per treatment rearing twin lambs and twelve ewes per treatment rearing single lambs (defined hereafter as rearing rank: $t w i n=2$ and single $=1$ ). Before euthanasia, the rectal temperature of each animal was recorded. Following euthanasia the liver, spleen, kidneys, perirenal adipose tissue, heart, lungs, thyroid and digestive tract were dissected and weighed. After excision, the abomasum was emptied along the mesentery and the contents collected in a $50 \mathrm{ml}$ sterile container (Sarstedt Ltd). The pH of the abomasal contents was then assessed using an Orion 3-Star $\mathrm{pH}$ meter (Thermo Fisher Scientific Inc.).

Intestinal tissue from the duodenum (approximately $10 \mathrm{~cm}$ from the abomasum) and ileum (approximately $10 \mathrm{~cm}$ from the ileo-caecal junction) was aseptically isolated and fixed in $10 \%$ phosphate buffered formalin for villus height (VH) and crypt depth (CD) measurements. Additional sections of the duodenum and ileum were excised, emptied by dissecting along the mesentery and rinsed using PBS (Oxoid; Thermo Fisher Scientific Inc.). Approximately $1-2 \mathrm{~g}$ of duodenum, ileum, thyroid and perirenal adipose tissue were collected and placed in $10 \mathrm{ml}$ tubes (Sarstedt Ltd) containing $5 \mathrm{ml}$ of RNAlater ${ }^{\mathrm{TM}}$ (Applied Biosystems Ltd), where they were stored for $24 \mathrm{~h}$. The RNALater ${ }^{\mathrm{TM}}$ was then removed and the tissue samples were stored at $-80^{\circ} \mathrm{C}$.

\section{Lamb weight and factory data collection}

All lambs were weighed fortnightly from days 14-70 postpartum and once every $28 \mathrm{~d}$ thereafter until slaughter. Lambs were weighed on an electronic scale and live weight recorded electronically. Lambs were slaughtered once they reached $45 \mathrm{~kg}$ live weight. Any lambs drafted before or after this weight was reached had their days-to-slaughter corrected for live weight before statistical analysis. At slaughter, carcass weights were recorded and subsequently used to calculate kill-out percentage (KO\%).

\section{Laboratory analysis}

Proximate analysis. The DM content $(\mathrm{g} / \mathrm{kg})$ of the concentrate and grass silage was determined by drying the samples at $55^{\circ} \mathrm{C}$ 
Table 2. Major and trace element composition of silage and concentrate offered to ewes during late gestation*

\begin{tabular}{lrr}
\hline & Silage & Concentrate \\
\hline Major elements (g/kg DM) & & \\
$\mathrm{Ca}$ & 4.9 & 4.48 \\
$\mathrm{Na}$ & 1.6 & 2.78 \\
$\mathrm{Mg}$ & 1.4 & 2.08 \\
$\mathrm{~K}$ & 31.3 & 10.78 \\
$\mathrm{P}$ & 2.7 & 4.40 \\
$\mathrm{Cl}$ & 11.5 & 4.58 \\
Trace elements (mg/kg DM) & & \\
$\mathrm{Cu}$ & 9.3 & 8.8 \\
$\mathrm{Fe}$ & 608.0 & 237.0 \\
$\mathrm{Mn}$ & 71.0 & 71.3 \\
$\mathrm{Zn}$ & 36.0 & 94.0 \\
$\mathrm{I}$ & 1.5 & 3.9 \\
$\mathrm{Co}$ & 0.2 & 1.3 \\
$\mathrm{Mo}$ & 4.3 & 1.6 \\
$\mathrm{Se}$ & 0.2 & 0.6 \\
\hline
\end{tabular}

* Mineral analysis of silage and concentrate, without the addition of the I supplement was carried out by Sciantec Analytical Services Ltd.

for $72 \mathrm{~h}$ in a ventilated oven with forced-air circulation. $\mathrm{N}$ content $(\mathrm{g} / \mathrm{kg} \mathrm{DM})$ of the silage and concentrate was determined using a LECO FP528 instrument (Leco Instruments Ltd) according to the method of Dumas ${ }^{(21)}$. The $\mathrm{N}$ concentration of the concentrate and grass silage was multiplied by 6.25 to determine CP concentrations ${ }^{(22)}$. The neutral detergent fibre (assayed with and without a heat stable amylase for concentrate and grass silage samples, respectively, and without sodium sulphite for both feeds; expressed inclusive of residual ash), acid detergent fibre (expressed inclusive of residual ash) and acid detergent lignin (expressed inclusive of residual ash) concentrations $(\mathrm{g} / \mathrm{kg} \mathrm{DM})$ of the feedstuff were determined ${ }^{(23)}$ using an $\mathrm{ANKOM}^{200}$ Fibre Analyzer (ANKOM Technology). Ash concentrations $(\mathrm{g} / \mathrm{kg} \mathrm{DM})$ of the feedstuff were determined by complete combustion in a muffle furnace at $550^{\circ} \mathrm{C}$ for $4 \mathrm{~h}$. The gross energy concentration $(\mathrm{MJ} / \mathrm{kg} \mathrm{DM})$ of the silage and concentrate was determined using bomb calorimetry (Parr 1281 bomb calorimeter; Parr Instrument Company $)^{(24)}$, whereas the $\mathrm{ME}$ concentration ( $\mathrm{MJ} / \mathrm{kg} \mathrm{DM})$ was calculated using the following equation $^{(24)}$ :

$$
100 \times \mathrm{ME} / \mathrm{DE}=86 \cdot 38-0 \cdot 099 \mathrm{CFO}-0 \cdot 196 \mathrm{CPo},
$$

where $\mathrm{CFO}$ is crude fibre in the organic matter and $\mathrm{CPO}$ is $\mathrm{CP}$ in the organic matter.

Diethyl ether extract concentrations ( $\mathrm{g} / \mathrm{kg} \mathrm{DM})$ of the feedstuff were determined using light petroleum ether and Soxtec instrumentation (Tecator). The concentration of starch in the concentrate was determined using the Megazyme Total Starch Assay Procedure ${ }^{(21)}$. Mineral analysis of silage and concentrate without the addition of the I supplement was carried out by Sciantec Analytical Services Ltd and is presented in Table 2.

Blood sample analysis. Total serum Ig concentration $(\mathrm{g} / \mathrm{l})$ was determined using the zinc sulphate turbidity test ${ }^{(25)}$. These results were then reduced by a factor of 0.09 to provide the IgG-only content of the serum ${ }^{(26)}$. The efficiency of IgG absorption within the first $24 \mathrm{~h}$ postpartum was further calculated. It was assumed that in lambs, as in calves, 0.075 of birth weight is equivalent to blood plasma volume ${ }^{(27)}$. Therefore, the following equation was used to calculate the IgG absorption efficiency:

$$
\begin{aligned}
& \text { IgG absorption }= \\
& \left(\frac{\text { Birth weight } \times 0 \cdot 075 \times \text { Serum IgG concentration }}{\text { Total IgG fed }}\right) \times 100 .
\end{aligned}
$$

Plasma total tri-iodothyronine $\left(\mathrm{T}_{3}\right)$ and total thyroxine $\left(\mathrm{T}_{4}\right)$ concentrations were determined using commercial RIA kits $\left(\mathrm{T}_{3}\right.$ : KIP1631 or $\mathrm{T}_{4}$ : KIP1641; DIAsource ImmunoAssays S.A.) where all samples were measured on the same assay in duplicate. The intra-assay CV were 3.85 and $4.96 \%$ for the $\mathrm{T}_{3}$ and $\mathrm{T}_{4}$ assays, respectively.

Colostrum analysis. The N content ( $\mathrm{g} / \mathrm{kg} \mathrm{DM})$ of the colostrum was determined using a LECO FP528 instrument according to the method of Dumas ${ }^{(21)}$. The $\mathrm{N}$ concentration in the colostrum was multiplied by 6.38 to determine CP concentrations ${ }^{(22)}$. The TS $(\mathrm{g} / \mathrm{l})$ content of the colostrum was determined using a direct forced-air method where $3 \mathrm{ml}$ of colostrum and/or milk were placed in an oven for $4 \mathrm{~h}$ at $100^{\circ} \mathrm{C}^{(23)}$.

The colostrum samples were thawed at room temperature the day before laboratory analysis. IgG concentration of the samples was determined by the ELISA method (Ovine IgG ELISA Kit, Cat. No. 7620; Alpha Diagnostic International). Samples were diluted 1:1000 000 before being assayed in duplicate, with an inter-assay $\mathrm{CV}$ of $5 \%$. The concentration of $\mathrm{IgG}$ in the samples was calculated from a standard reference curve containing known concentrations of IgG. Any sample that resulted in an IgG concentration that fell outside the range of the standard reference curve was retested after further dilution according to the test recommendations.

Duodenal and ileal morphology. The preserved intestinal segments were prepared using standard paraffin-embedding techniques. Cross-sections of $5 \mu \mathrm{m}$ thickness of each sample were stained with haematoxylin-eosin ${ }^{(28)}$. VH and CD were measured on the stained sections of the ileal tissue and only $\mathrm{VH}$ measurements were taken from the duodenal tissue, using a light microscope $(100 \times$ objective) fitted with an image analyser (Image-Pro Plus 9.1; Media Cybernetics). Measurements of twenty well-orientated intact villi and crypts were measured for each animal. VH was measured from the crypt-villus junction to the tip of the villus and CD was measured from the crypt-villus junction to the base.

Extraction and assessment of RNA integrity. Total RNA was isolated from the ileum, duodenum, thyroid and perirenal adipose tissues using TRI reagent (Molecular Research Center) according to the manufacturer's instructions, followed by further purification with the GenElute Mammalian Total RNA Miniprep Kit (SigmaAldrich). In brief, approximately $25 \mathrm{mg}$ of tissue was homogenised in $1.0 \mathrm{ml}$ of Trizol using a steel bead (Qiagen Ltd) and the Qiagen Tissuelyser II $(2 \times 120 \mathrm{~s}$ maximum speed). Chloroform $(200 \mu \mathrm{l})$ was then added to each sample, and following centrifugation (12 $000 \mathrm{~g}, 15 \mathrm{~min}$ ), the aqueous phase was transferred directly onto an RNeasy column (Qiagen Ltd). The RNA was further purified as 
per the manufacturer's instructions and included an on-column DNase step (Sigma-Aldrich).

The total RNA was quantified using a NanoDrop ND-1000 Spectrophotometer (Thermo Fisher Scientific Inc.) and the purity was assessed by determining the ratio of the absorbance at 260 and $280 \mathrm{~nm}$. All total RNA samples with acceptable 260:280 nm ratios were used for further analysis. Total RNA was analysed in an Agilent 2100 Bioanalyzer (Agilent Technologies, Inc.) using RNA 6000 Nano LabChips (Caliper Technologies Corp.). The RNA Integrity Number for the ileum, duodenum, thyroid and perirenal adipose tissues were 9.1 (SEM 0.06); 9.0 (SEM 0.08); 9.2 (sem 0.15) and 8.7 (SEM 0.19), respectively.

\section{Complementary DNA synthesis and quantitative real-time}

$P C R$. Total RNA from each sample $(1 \mu \mathrm{g})$ was reverse transcribed using the high capacity complementary DNA (cDNA) reverse transcription kit (Applied Biosystems Ltd) according to the manufacturer's instructions. The purified cDNA was diluted in RNase- and DNase-free water to a volume of $250 \mu \mathrm{l}$ and stored at $-20^{\circ} \mathrm{C}$. Oligonucleotide primers were designed with Primer Express ${ }^{\mathrm{TM}}$ Software, version 2.0 (Applied Biosystems) and synthesised by MWG-Biotech. All assays were assessed for specificity using dissociation analysis. Assays with efficiencies between 90 and $110 \%$ were deemed acceptable. Target genes quantified in the ileum and duodenum were: Fc fragment of the IgG receptor transporter, $\alpha$ (FCGRT), Fc receptor, IgA, IgM high affinity $(F C A M R)$, polymeric Ig receptor (PIGR), $\beta$-2-microglobulin $(B 2 M)$, cellular myelocytomatosis oncogene, $T N F \alpha$, upstream stimulator factor 1 (USF1), upstream stimulator factor 2 (USF2), thyroid hormone receptor- $\alpha$ (THRA), thyroid hormone receptor- $\beta$ (THRB), the ras-related proteins (RAB) $R A B 11 a$ and $R A B 25$ and the mucin genes (MUC) MUC1 and MUC3A; whereas THRA, THRB and uncoupling protein 1 (UCP1) were quantified in the thyroid and perirenal adipose tissues of lambs. All primer sequences for the target and reference genes were as presented in a previous study ${ }^{(12)}$.

The quantitative PCR (qPCR) assays were performed in a total volume of $20 \mu \mathrm{l}$, containing $2 \times$ Fast SYBR PCR Master Mix (Life Technologies Ltd), $1 \mu \mathrm{l}$ of a forward and reverse primer mix (300 nm each) and $5 \mu \mathrm{l}$ cDNA. qPCR was carried out in duplicate, on the 7500 ABI Prism Sequence Detection System (Applied Biosystems Ltd). Thermocycling conditions were as follows: $95^{\circ} \mathrm{C}$ for $10 \mathrm{~min}$, followed by $95^{\circ} \mathrm{C}$ for $15 \mathrm{~s}$, and $60^{\circ} \mathrm{C}$ for $1 \mathrm{~min}$ for forty cycles.

A total of six potential reference genes: $\beta$-actin, glyceraldehydes-3-phosphate dehydrogenase (GAPDH), glucose-6-phosphate dehydrogenase, hypoxanthine phosphoribosyltransferase 1 (HPRT1), ribosomal protein L19 and succinate dehydrogenase (SUCD) were analysed using the geNorm algorithm on the qbase + package (Biogazelle) ${ }^{(25)}$. GAPDH and SUCD were the most stably expressed in the ileum, duodenum and thyroid, and were subsequently used to normalise the gene expression data in these tissues; while HPRT1 and SUCD were used to normalise the gene expression data in the perirenal adipose tissue. The mean $C_{t}$ values of duplicates of each sample were used by the qBASE plus algorithm to generate the normalised relative quantities for each gene.
Determination of faecal egg count. Faecal samples were collected per rectum from all lambs once fortnightly from days 42-70 postpartum. All samples were placed on ice until their return to the laboratory where they were stored at $4^{\circ} \mathrm{C}$ before assessment. Faecal egg count (FEC) were determined using the modified McMaster method ${ }^{(29,30)}$. FEC was distinguished separately as ' $N$. battus' $\left(\mathrm{FEC}_{\mathrm{N}}\right.$ ) and 'other trichostrongyles' $\left(\mathrm{FEC}_{\mathrm{OT}}\right)$ with the number of eggs/g (epg) enumerated. Before statistical analysis, FEC values were transformed using the natural logarithm $\left(\log _{\mathrm{e}}(X+25)\right)$ to stabilise the variance.

\section{Statistical analysis}

In this study there are two treatment groups; $\mathrm{C}$ and I. The difference $(\mu 1-\mu 2)$ is expressed as a percentage of $\mu 1$ : that is, $(\mu 1-\mu 2) / \mu 1 \times 100$ and denoted by $d$. The CV is by definition $\sigma / \mu 1 \times 100$. According to the University College Dublin Animal Research Ethics Committee guidelines the formula is written as $n 2 \times(\mathrm{CV} / d)^{2} \times(1.96+0.842)^{2}$, that is, $n 15.7 \times(\mathrm{CV} / d)^{2}$. Lamb performance in terms of growth rate is the most important outcome variable in this study. Comparisons with the control were based on a significance level of $5 \%$ and a power of $80 \%$. From previous work $\mathrm{CV}=18 \%$ and $d=10 \%{ }^{(19)}$. Taking this into account the sample size per group is $n 15.7 \times(13.5 / 10)^{2}=50 \cdot 9$. In each treatment, twelve lambs were euthanised, and a natural mortality of $4 \%$ was assumed. Therefore, in order to retain fifty-one lambs per treatment for growth rate studies, thirty-two twin-bearing ewes per treatment were required.

Data were analysed as a completely randomised block design using the mixed model procedure (PROC MIXED) in SAS ${ }^{(31)}$. The binary data, namely lamb health, was analysed using PROC GENMOD. The individual ewe was considered the experimental unit for all parameters analysed. Descriptive statistics were performed to identify continuous and categorical variables and their distributions analysed to fit the assumptions of normality using the UNIVARIATE procedure. The statistical model used for all parameters included the fixed effect of treatment, whereas the ewe data was adjusted for live weight at the beginning of the experiment by covariance. Date of birth was fitted as a covariate for all lamb parameters analysed. A repeated measure analysis was performed on ewe DM intake, live weight, BCS and colostrum production data, and lamb live weight and FEC data. In all, six covariance structures were compared: compound symmetry, heterogeneous compound symmetry, autoregressive order 1, heterogeneous autoregressive order 1, toeplitz and heterogeneous toeplitz; whereas the covariance structure that yielded the lowest Bayesian information criterion was used in the model. The fixed effects of time (as the repeated constant), treatment, sex, rearing rank, the two-way interaction of ewe nutritional treatment $\times$ time and rearing rank $\times$ time were included in the model. A total of four ewes ( $n$ 2/treatment) gave birth to one lamb plus one mummified fetus and these were excluded from the final analysis. Therefore, the final number of ewes used for analysis in each treatment $(n)$ were thirty and thirty for the C and I treatments, respectively. There was no interaction between ewe nutritional treatment $\times$ rearing rank $(P>0 \cdot 25)$; therefore, it was removed 
from the model before the final analysis of lamb weight and growth rate data. Rearing rank wasn't a significant factor influencing $\mathrm{FEC}_{\mathrm{N}}$ or $\mathrm{FEC}_{\mathrm{OT}}(P>0.05)$ hence it was removed from the final model before analysis. Lamb birth weight was included as a covariate in the analysis of lamb growth rate data. A Tukey's adjustment was applied where multiple observations were compared in the final analysis. All data presented in the tables and figures are expressed as least-square means with their standard errors. The probability value, which denotes statistical significance, was $P<0.05$, while values tending towards significance were $0 \cdot 05<P<0 \cdot 10$.

\section{Results}

Ewe DM, crude protein and metabolisable energy intake, live weight and body condition score

Dietary treatment had no effect on the DM intake (1.29 v. 1.29 $(\operatorname{sem} 0 \cdot 01) \mathrm{kg} / \mathrm{d}), \mathrm{CP}(190 v .189(\operatorname{sem} 2.72) \mathrm{g} / \mathrm{d})$ or the ME intake $(13.26 v .13 .20$ (SEM 0.13) ME/ewe per d) of ewes throughout the feeding period $(P>0 \cdot 05)$. I supplementation had no effect on the live weight, BCS or BCS change of the ewes $(P>0.05)$ when assessed throughout the experimental period (data not shown).

\section{Lambing parameters}

I supplementation had no effect on ewe GL, LD or the combined litter weight of lambs at birth, with means ranging from 9.55 to 9.66 (SEM 0.126 ) kg, for the $\mathrm{C}$ and I progeny, respectively $(P>0.05)$. I supplementation did not affect the incidence of joint-ill or E.coli infection from birth until day 14 postpartum (P 0.235; data not shown).

\section{Colostrum yield, IgG concentration and intake}

Treatment had no effect on colostrum yield or IgG concentration at 1,10 and $18 \mathrm{~h}$ postpartum or on the total yield to $18 \mathrm{~h}$ $(P>0.05)$. There was no effect of I supplementation on the TS or CP concentrations in the colostrum $(P>0.05$; data not shown).

Dietary treatment had no effect on the intake of colostrum or IgG when measured at 1,10 and $18 \mathrm{~h}$ postpartum or on an absolute basis to $18 \mathrm{~h}$ ( $P>0.05$; data not shown). Similarly, there was no effect of dietary treatment on the volume of colostrum or on the quantity of IgG fed, per kg of lamb birth weight, to lambs in both the $\mathrm{C}$ and I treatment groups. However, excess I supplementation of the ewe reduced the absorption efficiency of colostral $\operatorname{IgG}$ within the first $18 \mathrm{~h}$ postpartum $(P<0.0001$; data not shown).

\section{Blood metabolites}

Thyroid hormone concentration. Supplementation of the ewe with excess I in late gestation tended to increase the concentration of total $\mathrm{T}_{3}(P 0.07$; Table 3$)$ and increased the concentration of total $\mathrm{T}_{4}$ at $24 \mathrm{~h}$ postpartum $(P<0.05)$. There was no effect of dietary treatment on the concentration of total $\mathrm{T}_{4}$ in the lamb serum at either 1 or $24 \mathrm{~h}$ postpartum $(P>0.05)$. However, lambs born to I-supplemented ewes had a lower
Table 3. The effect of prepartum dam nutritional treatment on ewe ( $n$ 30/treatment) and lamb ( $n$ 60/treatment) total tri-iodothyronine $\left(\mathrm{T}_{3}\right)$ and thyroxine $\left(\mathrm{T}_{4}\right)(\mathrm{nmol} / \mathrm{l})$ concentrations

\begin{tabular}{|c|c|c|c|c|}
\hline & \multicolumn{2}{|c|}{ Treatment } & \multirow[b]{2}{*}{ SEM } & \multirow[b]{2}{*}{$P$} \\
\hline & $\mathrm{C}$ & I & & \\
\hline \multicolumn{5}{|c|}{ Ewes (24h postpartum) } \\
\hline Total $\mathrm{T}_{4}$ & 71.67 & $119 \cdot 3$ & 14.91 & 0.007 \\
\hline Total $\mathrm{T}_{3}$ & $1 \cdot 86$ & $2 \cdot 44$ & 0.284 & 0.073 \\
\hline \multicolumn{5}{|c|}{ Lamb (1 h postpartum) } \\
\hline Total $\mathrm{T}_{4}$ & $72 \cdot 4$ & $73 \cdot 7$ & $12 \cdot 18$ & 0.928 \\
\hline Total $\mathrm{T}_{3}$ & 2.74 & 1.56 & 0.301 & 0.002 \\
\hline \multicolumn{5}{|c|}{ Lambs ( $24 \mathrm{~h}$ postpartum) } \\
\hline Total $\mathrm{T}_{4}$ & $87 \cdot 8$ & $83 \cdot 1$ & $4 \cdot 32$ & 0.452 \\
\hline Total $\mathrm{T}_{3}$ & $3 \cdot 71$ & $2 \cdot 88$ & 0.412 & 0.091 \\
\hline
\end{tabular}

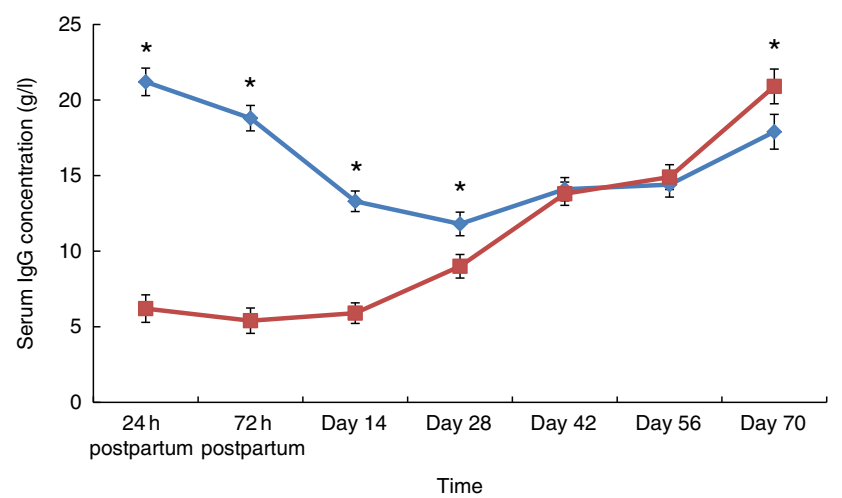

Fig. 1. The effect of prepartum dam nutritional treatment on the serum IgG concentration of the lamb postpartum. Treatments: $C$, basal diet, no added supplement (—); I, C plus $26.6 \mathrm{mg}$ of iodine added as calcium iodate $(--$ ). Values are least-square means (n 60 lambs per treatment for $24 \mathrm{~h}$ postpartum and $n 48$ lambs per treatment thereafter), with their standard errors. * Significant difference between $\mathrm{C}$ and I $(P<0.01)$. For a colour figure, see the online version of the paper.

serum concentration of total $\mathrm{T}_{3}$ at $1 \mathrm{~h}(P<0 \cdot 05)$. This effect tended to remain until $24 \mathrm{~h}$ postpartum $(P=0 \cdot 09)$.

Lamb serum IgG. The effect of dietary treatment on the serum IgG concentration of the progeny is presented in Fig. 1. Progeny of I ewes had lower concentrations of serum IgG from $24 \mathrm{~h}$ to day 28 postpartum $(P<0 \cdot 01)$; however, this had reversed on day 70 postpartum $(P<0.05)$ with the progeny of I ewes having higher concentrations of serum IgG when compared with the progeny of $\mathrm{C}$ ewes.

\section{Organ weights and small intestinal morphology}

Excess I supplementation to the ewe had no effect on the rectal temperature or abomasal $\mathrm{pH}$ of the progeny at $24 \mathrm{~h}$ postpartum ( $P>0.05$; data not shown). There was no effect of excess I supplementation to the ewe on the weight of the fetal digestive tract, liver, lungs, thyroid and kidneys when assessed on an absolute basis, at $24 \mathrm{~h}$ postpartum $(P>0 \cdot 05)$. The above results remained non-significant after correction for fetal birth weight 


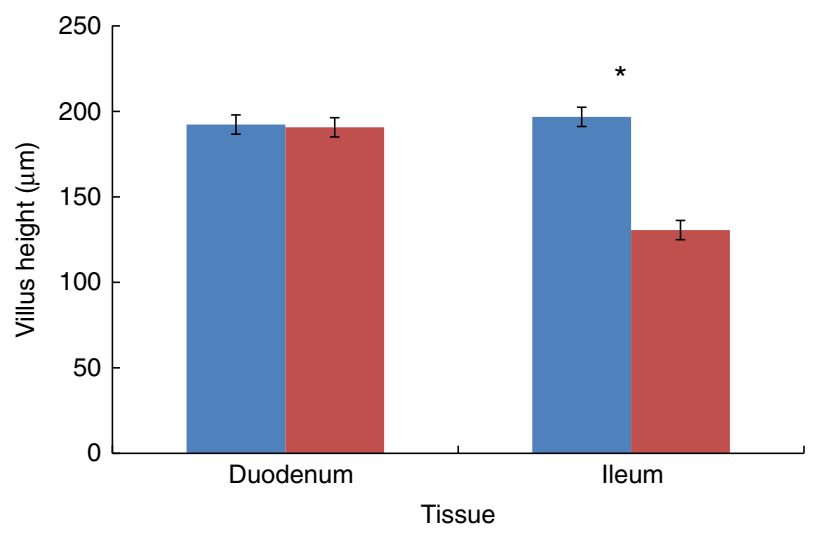

Fig. 2. The effect of prepartum dam nutritional treatment on the villus height $(\mu \mathrm{m})$ in the duodenum and the ileum of the lamb at $24 \mathrm{~h}$ postpartum. Treatments: C, basal diet, no added supplement ( $\square$ ); I, C plus $26.6 \mathrm{mg}$ of iodine added as calcium iodate $(\square)$. Values are least-square means ( $n 12$ lambs per treatment), with their standard errors represented by vertical bars. * Significant difference between $\mathrm{C}$ and I for villus height in the ileum $(P<0.01)$. For a colour figure, see the online version of the paper.

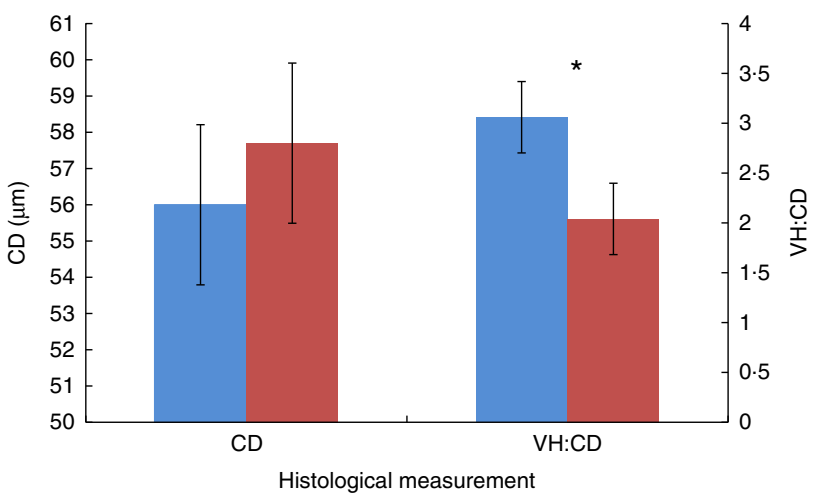

Fig. 3. The effect of prepartum dam nutritional treatment on the crypt depth (CD) and the villus height $(\mathrm{VH}): \mathrm{CD}$ ratio in the ileum of the lamb at $24 \mathrm{~h}$ postpartum. Treatments: C, basal diet, no added supplement ( $\square$ ); I, C plus $26.6 \mathrm{mg}$ of iodine added as calcium iodate $(\square)$. Values are least-square means ( $n 12$ lambs per treatment), with their standard errors represented by vertical bars. * Significant difference between $\mathrm{C}$ and I for $\mathrm{VH}: \mathrm{CD}$ ratio in the ileum $(P<0.01)$. For a colour figure, see the online version of the paper.

(data not shown). Dietary treatment affected the weight of the spleen $(P=0.05)$, which was $19 \%$ lighter, and tended to affect the weight of the perirenal adipose tissue $(P=0.06)$, which was $12 \cdot 8 \%$ lighter in the progeny of I ewes; however, these effects were not present after correction for fetal birth weight $(P>0.05)$. After correction for birth weight, the progeny of $\mathrm{C}$ ewes tended to have a lighter heart weight $(P=0 \cdot 09$; data not shown).

The effect of excess I supplementation on $\mathrm{VH}$ in the duodenum and ileum, and $\mathrm{CD}$ and $\mathrm{VH}: \mathrm{CD}$ ratio in the ileum of lambs at $24 \mathrm{~h}$ postpartum are shown in Fig. 2 and 3. Histological examination of the duodenum indicated there was no effect of dietary treatment on the $\mathrm{VH}$ at $24 \mathrm{~h}$ postpartum $(P>0.05)$. Progeny of the I ewes had a reduced $\mathrm{VH}$ and $\mathrm{VH}: \mathrm{CD}$ ratio $(P<0.01)$, despite the lack of difference in ileum CD $(P>0.05)$ at $24 \mathrm{~h}$ postpartum.

\section{Gene expression data}

Excess I supplementation to the ewe down-regulated the expression of $B 2 M$, and $T H R B$ in the ileum of the lamb at $24 \mathrm{~h}$ postpartum; while the expression of FCAMR and PIGR were up-regulated $(P<0.05$; Table 4). Supplementation of the ewe with excess I had no effect on the expression of FCGRT, THRA, USF1, USF2, RAB11a, TNF and MUC3a in the ileum of lambs at $24 \mathrm{~h}$ postpartum $(P>0 \cdot 05)$. Maternal dietary treatment tended to affect the mRNA expression of albumin $(A L B)$ in the ileum $(P=0.07)$, with lower levels expressed in the progeny of I-supplemented ewes. In the duodenum, there was no effect of maternal supplementation with excess I on the expression of FCAMR, FCGRT, PIGR, THRA, THRB, USF1, USF2, RAB11a and $T N F$ in lambs at $24 \mathrm{~h}$ postpartum $(P>0.05)$. The progeny of I-supplemented ewes had an increased expression of $R A B 25$, whereas the expression of MUC1 was down-regulated in the duodenum $(P<0 \cdot 05)$. There was no effect of dietary treatment on the mRNA expression of THRA and THRB in the thyroid tissue of lambs; however, the expression of THRB was down-regulated in the perirenal adipose tissue of I progeny $(P<0 \cdot 05$; Table 5$)$. In addition, there was no effect of excess I supplementation to the ewe on the expression of $U C P 1$ in the perirenal adipose tissue of lambs in the present study $(P>0.05)$.

\section{Lamb performance}

Live weight. There was no effect of excess I supplementation to the ewe on the live weight of the progeny from birth to day 98 postpartum (weaning; $P>0 \cdot 05$; Fig. 4.). There was an effect of rearing rank $(P=0 \cdot 001)$ from day 14 until weaning at day 98 postpartum; where single reared lambs remained heavier than those reared as twins. However, there was no interaction between ewe dietary treatment and rearing rank $(P>0.05)$ for lamb live weight.

Average daily gain. There was no effect of dietary treatment on the average daily gain (ADG) of progeny from days 0 to 42 postpartum $(P>0 \cdot 05$; Table 6$)$. The progeny of the I ewes had higher growth rates from days 42 to 70 postpartum $(P=0 \cdot 08)$ and from days 70 to $98(P<0 \cdot 05)$. Subsequently, the I progeny had increased growth rates $(P<0.05)$ from days 0 to 98 postpartum (birth to weaning; $291 v .271$ (SEM 9.4) g/d, respectively).

Slaughter data. There was no effect of excess I supplementation on the carcass weight of lambs ( $P=0.72$; data not shown), the ADG from birth to slaughter or weaning to slaughter $(P=0 \cdot 18$; Table 6) and the $\mathrm{KO} \%$ of lambs at slaughter $(P=0.64)$.

\section{Faecal egg counts}

The results of $\mathrm{FEC}_{\mathrm{N}}$ for lambs are shown in Table 7. There was an overall effect of excess I supplementation, such that I lambs had lower mean $\mathrm{FEC}_{\mathrm{N}}$ when compared with the progeny of C ewes $(P=0 \cdot 01)$. A treatment $\times$ time interaction was present whereby on day $42 \mathrm{I}$ lambs had lower $\mathrm{FEC}_{\mathrm{N}}$ than $\mathrm{C}$ lambs; however, this wasn't present on days 56 or 70 postpartum. 
Table 4. The effect of prepartum dam nutritional treatment on the normalised relative quantity of Ig-associated genes; TNFa and mucins in the ileum and duodenum of lambs at $24 \mathrm{~h}$ postpartum

(n 12 lambs per treatment)

\begin{tabular}{|c|c|c|c|c|c|c|c|c|}
\hline \multirow[b]{4}{*}{ Genes } & \multicolumn{6}{|c|}{ Tissue type } & & \\
\hline & \multicolumn{3}{|c|}{ Ileum } & \multicolumn{3}{|c|}{ Duodenum } & & \\
\hline & \multicolumn{6}{|c|}{ Treatment } & \multicolumn{2}{|c|}{ Treatment $(P)$} \\
\hline & $\mathrm{C}$ & I & SEM $^{2}$ & $\mathrm{C}$ & 1 & SEM & lleum & Duodenum \\
\hline THRA & 1.57 & 1.47 & 0.217 & 1.35 & $1 \cdot 27$ & 0.147 & 0.633 & 0.541 \\
\hline THRB & 2.05 & $1 \cdot 10$ & 0.394 & $1 \cdot 37$ & $1 \cdot 30$ & 0.204 & 0.027 & 0.708 \\
\hline FCGRT & 1.04 & $1 \cdot 19$ & 0.146 & 1.04 & 1.00 & 0.060 & 0.466 & 0.691 \\
\hline FCAMR & 1.51 & 2.65 & 0.375 & $1 \cdot 11$ & 1.02 & 0.276 & 0.041 & 0.757 \\
\hline PIGR & 0.87 & $1 \cdot 21$ & 0.149 & 1.02 & 0.77 & 0.340 & 0.043 & 0.490 \\
\hline B2M & $1 \cdot 10$ & 0.83 & 0.083 & 0.92 & 0.89 & 0.046 & 0.023 & 0.641 \\
\hline$A L B$ & $1 \cdot 70$ & 0.87 & 0.358 & $1 \cdot 22$ & 0.92 & 0.257 & 0.066 & 0.416 \\
\hline USF1 & 0.99 & $1 \cdot 16$ & 0.124 & 1.06 & 1.08 & 0.057 & 0.344 & 0.830 \\
\hline USF2 & 0.92 & 1.03 & 0.099 & $1 \cdot 10$ & 1.09 & 0.102 & 0.434 & 0.903 \\
\hline$R A B 11 a$ & 1.50 & $1 \cdot 22$ & 0.193 & 1.25 & $1 \cdot 27$ & 0.026 & 0.124 & 0.496 \\
\hline$R A B 25$ & $1 \cdot 14$ & 0.97 & 0.105 & 0.86 & 1.06 & 0.085 & 0.266 & 0.027 \\
\hline$T N F$ & $1 \cdot 27$ & 1.55 & 0.206 & 0.91 & 1.01 & 0.095 & 0.346 & 0.498 \\
\hline MUC1 & 1.07 & 0.97 & 0.134 & 0.93 & 0.52 & 0.186 & 0.619 & 0.028 \\
\hline МUСЗа & 6.06 & $7 \cdot 27$ & 1.913 & $3 \cdot 37$ & 3.70 & 0.998 & 0.506 & 0.818 \\
\hline
\end{tabular}

C, basal diet, no added supplement, I, ewes supplemented with $26.6 \mathrm{mg}$ of iodine added as calcium iodate; THRA, thyroid hormone receptor- $\alpha$; THRB, thyroid hormone receptor- $\beta$; FCGRT, Fc fragment of the IgG receptor transporter, a; FCAMR, Fc receptor, IgA, IgM high affinity; PIGR, polymeric Ig receptor; B2M, $\beta$-2-microglobulin; ALB, albumin; USF1, upstream stimulator factor 1; USF2, upstream stimulator factor 2; RAB, ras-related protein; MUC, mucin genes.

Table 5. The effect of prepartum dam nutritional treatment on the normalised relative quantity of Ig-associated genes in the thyroid and perirenal adipose tissue of lambs at $24 \mathrm{~h}$ postpartum

(n 12 lambs per treatment)

\begin{tabular}{|c|c|c|c|c|c|c|c|c|}
\hline \multirow[b]{4}{*}{ Genes } & \multicolumn{6}{|c|}{ Tissue type } & & \\
\hline & \multicolumn{3}{|c|}{ Thyroid } & \multicolumn{3}{|c|}{ Perirenal adipose tissue } & & \\
\hline & \multicolumn{6}{|c|}{ Treatment } & \multicolumn{2}{|c|}{ Treatment $(P)$} \\
\hline & C & I & SEM & $\mathrm{C}$ & I & SEM & Thyroid & Perirenal adipose tissue \\
\hline THRA & 1.07 & $1 \cdot 10$ & 0.129 & 0.98 & 0.89 & 0.123 & 0.871 & 0.490 \\
\hline THRB & $1 \cdot 12$ & 1.08 & 0.140 & $1 \cdot 21$ & 0.87 & 0.091 & 0.872 & 0.029 \\
\hline UCP1 & 0.85 & 0.77 & 0.288 & $1 \cdot 30$ & $1 \cdot 36$ & 0.125 & 0.852 & 0.608 \\
\hline
\end{tabular}

C, basal diet, no added supplement; I, ewes supplemented with $26.6 \mathrm{mg}$ of I added as calcium iodate; THRA, thyroid hormone receptor- $\alpha$; THRB, thyroid hormone receptor- $\beta$; UCP1, uncoupling protein 1

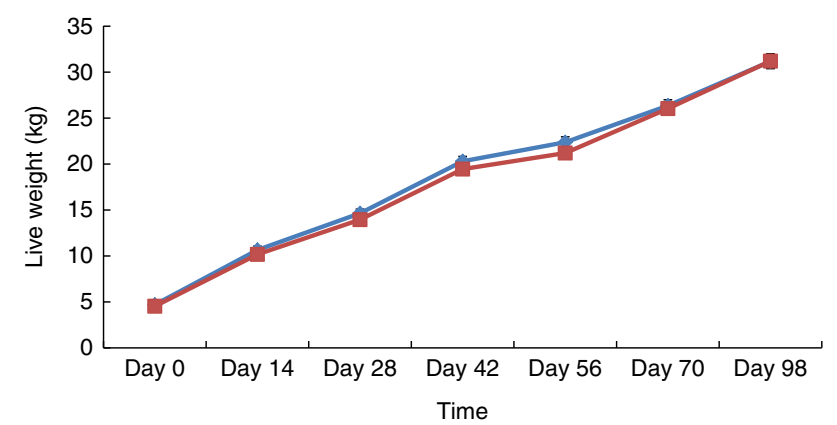

Fig. 4. The effect of prepartum dam nutritional treatment on lamb live weight postpartum. Treatments: C, basal diet, no added supplement (—); I, C plus $26.6 \mathrm{mg}$ of iodine added as calcium iodate (- - ). Values are least-square means ( $n 60$ lambs per treatment for 'day 0' (birth weight) and $n 48$ lambs per treatment thereafter), with their standard errors. For a colour figure, see the online version of the paper.

There was further evidence of a time effect whereby the number of faecal epg gradually increased with age at sampling.
There was no effect of excess I supplementation on the number of $\mathrm{FEC}_{\mathrm{OT}}$ observed from lambs ( $P>0.05$; Table 7$)$; however, there tended to be a time effect where the number of FEC $_{\mathrm{OT}}$ increased with age $(P=0 \cdot 08)$.

\section{Discussion}

Maternal I supplementation of the pregnant ewe has been shown to negatively influence serum IgG concentrations in her progeny immediately postpartum ${ }^{(11)}$, however, neonatal lambs are dependent upon passively acquiring maternal antibodies from the colostrum to confer disease resistance in early life. Therefore, the primary objectives of this study were: (1) to determine the effect of excess I supplementation to the pregnant ewe on the thyroid hormone status of both the ewe and her progeny at parturition; (2) to determine potential mechanisms responsible for FPT by examining the expression profiles of selected genes in the ileum, duodenum, thyroid and perirenal adipose tissue of the lamb at $24 \mathrm{~h}$ postpartum; and 
Table 6. The effect of prepartum dam nutritional treatment on lamb average daily gain (ADG), days-to-slaughter and kill-out percentage ( $n$ 48/treatment)

\begin{tabular}{lcccc}
\hline & \multicolumn{2}{c}{ Treatment } & & \\
\cline { 2 - 3 } & $\mathrm{C}$ & $\mathrm{I}$ & SEM & $P$ \\
\hline ADG between days (g/d) & & & & \\
$\quad$ Days 0†-14 & 332 & 314 & 13.5 & 0.341 \\
Days 0-42 & 313 & 313 & 9.8 & 0.999 \\
Days 0-98 & 271 & 292 & 9.4 & 0.029 \\
Day 98\$-slaughter* & 156 & 156 & 11.5 & 0.981 \\
$\quad$ Day 0-slaughter & 213 & 226 & 9.3 & 0.178 \\
Slaughter data & & & & \\
$\quad$ Days-to-slaughter & 193 & 187 & 10.3 & 0.557 \\
Kill out percentage & 46.19 & 46.58 & 0.827 & 0.637
\end{tabular}

C, basal diet, no added supplement; I, ewes supplemented with $26.6 \mathrm{mg}$ of I added as calcium iodate.

* Lambs were drafted for slaughter when they reached $45 \mathrm{~kg}$ body weight.

$\dagger$ Day $0=$ birth.

‡ Day 98 postpartum = weaning

(3) to assess the effect of FPT on the growing lambs' response to gastrointestinal infection. The results from this study include a down-regulation of THRB and $B 2 M$ and a reduction in $\mathrm{VH}$ in the ileum of I-supplemented progeny. Supporting previous work $^{(11)}$, which saw a decline in free $\mathrm{T}_{3}$, a decline in total $\mathrm{T}_{3}$ concentrations in the lamb were also observed in this study. These observations may explain in part the decline in IgG absorption at $24 \mathrm{~h}$ postpartum. However, despite the evident reduction in IgG absorption in lambs born to I-supplemented ewes, these lambs exhibited lower $\mathrm{FEC}_{\mathrm{N}}$ in response to a natural parasitic infection and enhanced growth performance. These observations have led us to hypothesise that lambs born to I-supplemented ewes develop a superior ability to fight infection to $N$. battus in later life.

Most dietary I becomes incorporated as a constituent of the thyroid hormones $\mathrm{T}_{4}$ and $\mathrm{T}_{3}$ in mammalian species ${ }^{(32,33)}$. In agreement with this, increased concentrations of both the thyroid hormones were observed in ewes supplemented with excess I in the present study. While placental transfer of both $\mathrm{T}_{3}$ and $\mathrm{T}_{4}$ is absent during the final two-thirds of gestation, the production of thyroid hormones by the fetus remains dependent of the uptake of iodide from maternal circulation ${ }^{(34)}$. However, in the present study, lambs born to I-supplemented ewes had lower concentrations of total $\mathrm{T}_{3}$ at 1 and $24 \mathrm{~h}$ postpartum and lower expression of THRB in the ileum at $24 \mathrm{~h}$ postpartum. This finding is in agreement with previous studies ${ }^{(6,12,35)}$ and may be partially explained by a disruption to the conversion of $\mathrm{T}_{4}$ to the biologically active $T_{3}$. In comparison with previous work, lower concentrations of total $\mathrm{T}_{4}$ were observed in this study ${ }^{(6)}$. Neonatal $\mathrm{T}_{4}$ concentrations are dependent on a thyroid-stimulating hormone surge which is further reliant on the intake of milk by the neonate after birth ${ }^{(34)}$. Therefore, the lack of milk consumption by the newborn lamb before blood sample collection at $1 \mathrm{~h}$ postpartum may in part explain the lower concentrations of $\mathrm{T}_{4}$ in the lambs at $1 \mathrm{~h}$ postpartum.

The level of I offered to ewes in the present study was in excess of dietary I requirements for both the $\mathrm{C}$ and I treatment groups $^{(36-38)}$ but did not exceed the stated toxicity level of $50 \mathrm{mg} /$ ewe per $\mathrm{d}^{(39)}$. Despite this increase in I intake, in excess

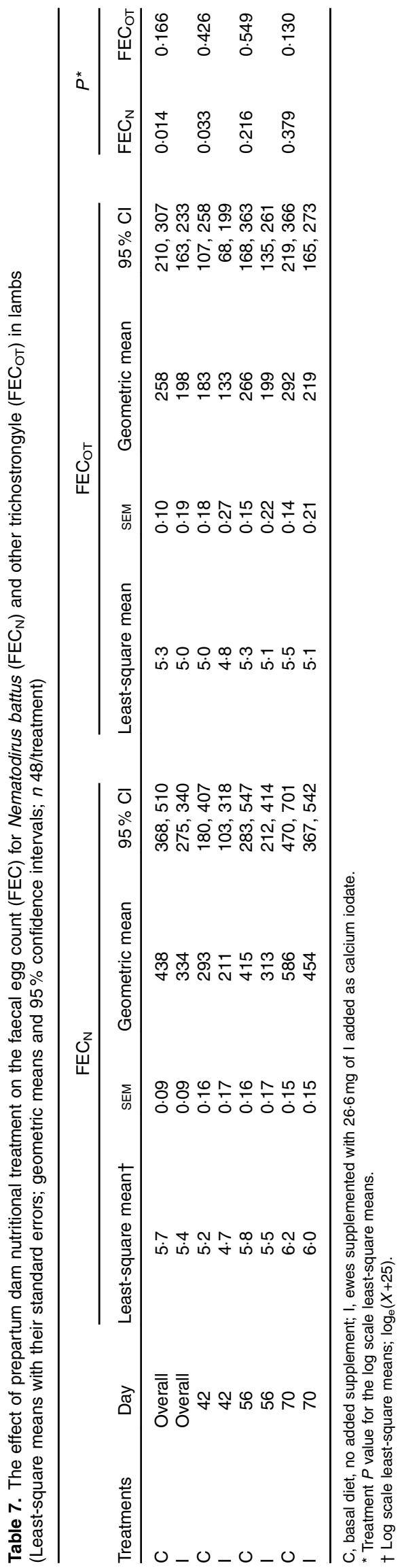


of requirement and the elevated production of the thyroid hormones, there were no effects on the performance parameters of the ewes including colostrum yield, composition and IgG concentration. However, in accordance with previous studies, FPT was evident in lambs at $24 \mathrm{~h}$ postpartum ${ }^{(6,13,40-42)}$. Because of the hypo-immunocompetent nature of the newborn ungulate $^{(6)}$, FPT has been linked to increases in susceptibility to infection and subsequent declines in health ${ }^{(43,44)}$. However, in the present study there was no decline in the number of lambs treated for either joint-ill or E.coli between birth and day 14 postpartum. Previous authors have suggested that the decline in serum IgG concentration is a result of a 'preprogramming' effect due to excess I supplementation and mediated through the thyroid hormones in the developing fetus ${ }^{(10,12)}$. In this study, the lower concentration of serum IgG, observed among lambs born to I-supplemented ewes, was evident until day 32 postpartum, after which the lamb normally produces its own internal antibodies ${ }^{(45)}$. This highlights the persistency of the preprogramming effect on serum IgG in the lamb; which had been previously reported at 24 and $72 \mathrm{~h}$ postpartum ${ }^{(6)}$. Supplementation of the ewe with minerals and more specifically I prepartum may lead to increased concentrations of the mineral in both the colostrum and milk of the ewe postpartum; however, previous work has shown that the progeny of I-fed dams had reduced serum IgG concentrations when fed either artificial colostrum ${ }^{(42)}$ or colostrum from control-fed ewes ${ }^{(10)}$

Previous authors have hypothesised that the resultant FPT, following excess I supplementation of the pregnant ewe, may be due to the $\operatorname{IgG}$ being rechannelled back into the intestinal lumen ${ }^{(32,37,46)}$. The absorption of $\operatorname{IgG}$ from the colostrum is mediated via the neonatal Fc Receptor $\left(F_{C} R n\right)^{(14)}$, which has been linked to both the transcytosis and recycling of $\operatorname{IgG}^{(47,48)}$. The primary site of IgG absorption in the newborn ruminant is in the lower ileum ${ }^{(14)}$ where there are two primary pathways of IgG absorption. First, IgG is bound to FcRn at the apical surface, forming an endosome, within which it is transcytosed to the basal surface, or alternatively, the IgG is engulfed into intestinal cells via fluid phase endocytosis before binding to FcRn and being transcytosed across intestinal epithelial cells ${ }^{(46,49,50)}$. Therefore, recycling of $\operatorname{IgG}$ back into the intestinal lumen requires transport from the basal to the apical surface ${ }^{(48)}$. Previous authors have reported the localisation of FCRn, which are known to mediate the recycling of IgG back into the intestinal lumen, at the apical side of duodenal crypt epithelial cells ${ }^{(32,37)}$. In the present study, there was no difference between the expression of the FcRn heavy chain component, FCGRT, in the ileum and the duodenum; however, an up-regulation of $R A B 25$ gene expression was observed in the duodenum. RAB25 is a member of the Rab GTPases family which are small intracellular proteins associated with the regulation of recycling or transcytosis of the endosome ${ }^{(46)}$. An in vitro study found that suppression of $R A B 25$ inhibited the bidirectional transcytosis of IgG by $25-50 \%{ }^{(50)}$. If the opposite effect were true, the up-regulation of $R A B 25$ in the duodenal tissue examined in the present study may indicate an increase in $\operatorname{Ig} G$ recycling from the basal to the apical surface of the intestinal tract.

A secondary function of the FcRn receptor is to protect IgG and albumin from catabolism, thus, indirectly increasing the serum half-life of both ${ }^{(51)}$. Higher serum concentrations of IgG can therefore be limited by the availability of FcRn, as unbound $\operatorname{IgG}$ is delivered to lysosomes where it is degraded ${ }^{(37)}$. Maternal supplementation with excess I down-regulated $B 2 M$ and tended to down-regulate $A L B$ in the ileum of lambs in the present study. In mice, a deletion in the light chain component of the FcRn receptor, B2M, has previously been linked to loss of FcRn expression and depletion of maternal IgG transport ${ }^{(52)}$ resulting in lower levels of both serum IgG and albumin ${ }^{(53)}$. Hence, the down-regulation of $B 2 M$, in conjunction with the decline in serum IgG concentrations, could indicate reduced expression of functional FcRn and therefore increased levels of IgG catabolism in the intestine of the lamb. A previous study which looked at the expression of $B 2 M$ in the ileum of the lamb, before colostrum consumption, reported a lower level of expression in $\mathrm{C}$ lambs at $1 \mathrm{~h}^{(12)}$. The increase in $B 2 M$ gene expression, from 1 to $24 \mathrm{~h}$ postpartum in control lambs, coincides with the ingestion of colostrum and is in agreement with previous work which found that $B 2 M$ was up-regulated in the mammary gland during the period of active $\operatorname{IgG}$ transfer $^{(32)}$. Despite the enhanced expression of $B 2 M$ at $1 \mathrm{~h}^{(12)}$ a similar pattern in expression was not observed in I-supplemented progeny over time. Thus, it would be beneficial to examine the catabolism of IgG along the digestive tract of newborn lambs in future experiments.

Colostrum intake promotes dramatic morphological and functional changes in the gastrointestinal tract of neonates including epithelial cell proliferation, migration and differentiation $^{(54)}$. In addition, the influence of the thyroid hormones on cellular differentiation, growth and development in the fetus and neonate ${ }^{(55)}$ has resulted in previous authors re-examining the impact of the thyroid hormones on the development and maturation of the gastrointestinal tract ${ }^{(12,55)}$. Following maternal supplementation with I, negative changes in the intestinal architecture of the lamb were observed (decreased $\mathrm{VH}$ and $\mathrm{VH}$ : $\mathrm{CD}$ ratio in the ileum), in the present study. Villi are fundamental components of the digestive tract and their geometry acts as an indicator of the absorptive capacity of the small intestine $^{(56)}$. Hence, the VH:CD ratio has been identified as a useful parameter in the evaluation of intestinal health ${ }^{(57)}$, with previous work reporting that the $\mathrm{VH}$ :CD ratio steadily increases in the lamb postnatally ${ }^{(58)}$. This is inconsistent with results obtained from the progeny of the I-supplemented ewes where a reduction in the $\mathrm{VH}: \mathrm{CD}$ ratio was observed at $24 \mathrm{~h}$ postpartum and is in accordance with the decline in the absorption of serum IgG.

To date, the decline in serum IgG concentration following maternal supplementation with excess I has not been investigated alongside the neonatal lambs' response to infection postpartum. The increasing prevalence of GIN infections and the evolution of anthelminthic resistant nematodes has increased the use of chemoprophylaxis in sheep production systems ${ }^{(59,60)}$; hence, there is growing interest in developing alternative parasite control strategies. $N$. battus is one of the earliest nematodes to cause infection in the growing lamb, establishing itself in the host animal from 6 weeks of age ${ }^{(61)}$ because of a temporary lapse in the immune-competence of the dam around the period of late pregnancy and early lactation ${ }^{(62)}$. 
Strategies which promote a robust immune response are therefore crucial to enhancing both the health and survival of the young lamb with regard to nematode infections ${ }^{(62)}$. Infection of growing lambs with GIN causes significant production losses through sub-optimal feed intake and nutrient utilisation ${ }^{(3,62)}$. Coinciding with a decline in $\mathrm{FEC}_{\mathrm{N}}$, animals born to I-supplemented ewes had higher growth rates from days 56 to 98 postpartum. Interestingly, results obtained from the present study show that lambs from I-supplemented ewes had an overall reduction in $\mathrm{FEC}_{\mathrm{N}}$, which was also evident on $\mathrm{d} 42$ postpartum. This coincides with a rise in serum IgG concentrations, which were higher on day 70 , among these lambs. Therefore, it may be hypothesised that the progeny of the I-supplemented ewes were primed for a heightened response to $N$. battus infection due to FPT in the neonatal period and the requirement to begin producing antibodies at an earlier age $v$. C lambs that had increased serum IgG concentrations in the postpartum period. Alternatively, lambs born to I-supplemented ewes may have been exposed to higher concentrations of $\mathrm{I}$ in the colostrum and milk during the postpartum period; thus proving toxic to $N$. battus in the gastrointestinal tract of the growing lamb.

In conclusion, the data presented in this study indicates that maternal supplementation with excess I during the late gestation period reduces serum IgG concentrations in the lamb; a decline that was evident up to day 28 postpartum. This FPT of IgG may be due in part to impaired intestinal integrity and down-regulation of $B 2 M$; which has the potential to reduce the total area available for absorption and increase the degradation of IgG in the intestine. Alternatively, the gene expression data from the duodenum indicate the possibility of recycling the IgG back into the intestinal lumen; however, further investigation into this is merited. Collectively, the results are mediated by the decline in $\mathrm{T}_{3}$ concentrations and a downregulation of THRB in the ileum. They provide new insights into the mechanisms governing FPT in the progeny of I-supplemented dams and highlight the effect this has on the lambs' own ability to produce IgG and subsequent positive responses to $N$. battus infection.

\section{Acknowledgements}

The authors wish to thank Dr Cormac O' Shea, Dr Maria Markiewicz-Keszycka and Dr Gaurav Rajauria for their assistance with laboratory analysis and Mr Philip Brady for his help with animal management. Thanks are also extended to Ms Denise Rafferty for her assistance with sample collection and the Irish Research Council from whom the research described herein was funded.

This study was funded by the Irish Research Council (grant no: RS/2012/103) under the Government of Ireland postgraduate scholarship scheme. The Irish Research Council had no role in the design, analysis or writing of this article.

The authors' contributions are as follows: F. Mc. G. wrote the manuscript, collected the samples and carried out the laboratory and statistical analysis; T. M. B. was the principal investigator responsible for the design of the experiment, sample collection and supervision of the data collection and statistical analysis. T. M. B and T. S.corrected the manuscript; T. S. designed the study and supervised the laboratory analysis; M. T. R. assisted and supervised the laboratory analysis; F. P. C. and S. L. contributed to the sample and data collection. All authors approved the final version of the manuscript.

The authors declare that there are no conflict of interest.

\section{References}

1. Sawalha R, Conington J, Brotherstone S, et al. (2007) Analyses of lamb survival of Scottish Blackface sheep. Animal 1, 151-157.

2. Dwyer CM (2008) The welfare of the neonatal lamb. Small Rumin Res 76, 31-41.

3. Good B, Hanrahan J, Crowley B, et al. (2006) Texel sheep are more resistant to natural nematode challenge than Suffolk sheep based on faecal egg count and nematode burden. Vet Parasitol 136, 317-327.

4. Denwood M, Stear M, Matthews L, et al. (2008) The distribution of the pathogenic nematode Nematodirus battus in lambs is zero-inflated. Parasitology 135, 1225-1235.

5. Brambell FWR (1970) The transmission of passive immunity from mother to young. In The Transmission of Passive Immunity from Mother to Young, pp. xvi + 385 [A Neuberger and EL Tatum, editors]. Amsterdam: North Holland Publishing Co.

6. Boland TM, Hayes L, Sweeney T, et al. (2008) The effects of cobalt and iodine supplementation of the pregnant ewe diet on immunoglobulin $\mathrm{G}$, vitamin $\mathrm{E}, \mathrm{T} 3$ and $\mathrm{T} 4$ levels in the progeny. Animal 2, 197-206.

7. Rose M, Pearson S \& Cratchley T (2012) Effect of iodine, selenium and cobalt rumen boluses given to dry dairy cows on the immunoglobulin and thyroid hormone status of calves. Anim Sci J 83, 543-548.

8. Park SC \& Jacobson NL (1993) The mammary gland and lactation. In Dukes' Physiology of Domestic Animals, pp. 711-727 [MJ Swenson and WO Reece, editors]. New York: Comstock Publishing Company Inc.

9. Winter MD, Wright C \& Lee DL (2002) The mast cell and eosinophil response of young lambs to a primary infection with Nematodirus battus. Parasitology 114, 189-193.

10. Boland T, Keane N, Nowakowski P, et al. (2005b) High mineral and vitamin $\mathrm{E}$ intake by pregnant ewes lowers colostral immunoglobulin G absorption by the lamb. J Anim Sci 83, 871-878.

11. Mayer B, Doleschall M, Bender B, et al. (2005) Expression of the neonatal $\mathrm{Fc}$ receptor $(\mathrm{FCRn})$ in the bovine mammary gland. J Dairy Res 72, 107-112.

12. McGovern FM, Magee DA, Browne JA, et al. (2016) Iodine supplementation of the pregnant dam alters intestinal gene expresison and subsequent immunoglobulin uptake in the newborn lamb. Animal 10, 598-606.

13. Boland TM., Brophy PO, Callan JJ, et al. (2004) The effects of mineral-block components when offered to ewes in late pregnancy on colostrum yield and immunoglobulin G absorption in their lambs. Anim Sci 79, 293-302.

14. Yvon M, Levieux D, Valluy MC, et al. (1993) Colostrum protein digestion in newborn lambs. J Nutr 123, 586-596.

15. Russel A (1984) Means of assessing the adequacy of nutrition of pregnant ewes. Livest Prod Sci 11, 429-436.

16. Agricultural and Food Research Council (1993) Energy and Protein Requirements of Ruminants; An Advisory Manual Prepared by the AFRC Technical Committee on Responses to Nutrients. Oxford: CAB International.

17. Robinson J, Rooke J \& McEvoy T (2002) Nutrition for conception and pregnancy. Canberra: CABI Publishing CSIRO Publishing. 
18. Crosby TF, Boland TM, Brophy PO, et al. (2004) Effects of offering mineral blocks to ewes pre-mating and in late pregnancy on block intake, pregnant ewe performance and immunoglobulin status of the progeny. Anim Sci 79, 493-504.

19. McGovern FM, Campion FP, Lott S, et al. (2015) Altering ewe nutrition in late gestation (I) the impact on pre- and postpartum ewe performance. J Anim Sci 93, 4860-4872.

20. Doney J, Peart J, Smith W, et al. (1979) A consideration of the techniques for estimation of milk yield by suckled sheep and a comparison of estimates obtained by two methods in relation to the effect of breed, level of production and stage of lactation. J Agric Sci 92, 123-132.

21. Association of Official Analytical Chemists (1990) Official Methods of Analysis, 15th ed. Arlington, VA: AOAC.

22. Kjeldahl J (1883) A new method for the determination of nitrogen in organic matter. $Z$ Anal Chem 22, 366.

23. Van Soest PJ, Robertson J \& Lewis B (1991) Methods for dietary fiber, neutral detergent fiber, and nonstarch polysaccharides in relation to animal nutrition. J Dairy Sci $\mathbf{7 4}$, 3583-3597.

24. Sauvant D, Perez JM, Tran G, et al. (2004) Tables of Composition and Nutritional Value of Feed Materials (Pigs, Poultry, Cattle, Sheep, Goats, Rabbits, Horses and Fish). Wageningen: Wageningen Academic Publishers.

25. McEwan A, Fisher E \& Selman I (1970) Observations on the immune globulin levels of neonatal calves and their relationship to disease. J Comp Pathol 80, 259-265.

26. Larson RE, Ward A, Frederiksen K, et al. (1974) Capability of lambs to absorb immunoproteins from freeze-dried bovine colostrum. Am J Vet Res 35, 1061-1063.

27. Quigley JD, Hammer CJ, Russel LE, et al. (2005) Passive immunity in newborn calves. In Calf and Heifer Rearing, pp. 135-157 [PC Garnsworthy, editor]. Nottingham: Nottingham University Press.

28. Pierce K, Sweeney T, Brophy P, et al. (2006) The effect of lactose and inulin on intestinal morphology, selected microbial populations and volatile fatty acid concentrations in the gastro-intestinal tract of the weanling pig. Anim Sci 82, 311-318

29. Ministry of Agriculture Fisheries and Food (1986) Manual of Veterinary Parasitological Laboratory Techniques. London: Reference Book 418.

30. Kelly P, Good B, Hanrahan J, et al. (2009) Screening for the presence of nematophagous fungi collected from Irish sheep pastures. Vet Parasitol 165, 345-349.

31. Statistical Analysis System (SAS) (2013) SAS Users Guide, 9.4. Cary, NC: SAS Institue Inc.

32. Mayer B, Zolnai A, Frenyo LV, et al. (2002) Redistribution of the sheep neonatal $F_{C}$ receptor in the mammary gland around the time of parturition in ewes and its localization in the small intestine of neonatal lambs. Immunology 107, 288-296.

33. Zhu X, Peng J, Raychowdhury R, et al. (2002) The heavy chain of neonatal Fc receptor for IgG is sequestered in endoplasmic reticulum by forming oligomers in the absence of $\beta 2$-microglobulin association. Biochem J 367, 703-714.

34. Forhead AJ \& Fowden AL (2014) Thyroid hormones in fetal growth and prepartum maturation. J Endocrinol 221, R87-R103.

35. Cabello G \& Wrutniak C (1986) Plasma free and total iodothyronine levels in the newborn lamb. Physiological considerations. Reprod Nutr Dev 26, 1281-1288.

36. National Research Council (1985) Nutrient Requirements of Sheep, 6th rev. ed. Washington, DC: The National Academic Press.

37. Cervenak J \& Kacskovics I (2009) The neonatal Fc receptor plays a crucial role in the metabolism of $\operatorname{IgG}$ in livestock animals. Vet Immunol Immunopatbol 128, 171-177.
38. Korhonen H, Marnila P \& Gill H (2000) Milk immunoglobulins and complement factors. Br J Nutr 84, 75-80.

39. Agricultural Research Council (1980) The Nutrient Requirements of Ruminant Livestock. Farnham Royal: Commonwealth Agricultural Bureaux.

40. Boland TM, Brophy PO, Callan JJ, et al. (2005a) The effects of mineral supplementation to ewes in late pregnancy on colostrum yield and immunoglobulin $G$ absorption in their lambs. Livest Prod Sci 97, 141-150.

41. Boland T, Callan J, Brophy P, et al. (2006) Lamb serum vitamin E and immunoglobulin $\mathrm{G}$ concentrations in response to various maternal mineral and iodine supplementation regimens. Anim Sci 82, 319-325.

42. Rose MT, Wolf BT \& Haresign W (2007) Effect of the level of iodine in the diet of pregnant ewes on the concentration of immunoglobulin $\mathrm{G}$ in the plasma of neonatal lambs following the consumption of colostrum. Br J Nutr 97, 315-320.

43. Donovan GA, Dohoo IR, Montgomery DM, et al. (1998) Associations between passive immunity and morbidity and mortality in dairy heifers in Florida, USA. Prev Vet Med 34, 31-46.

44. Quigley J (2004) The role of oral immunoglobulins in systemic and intestinal immunity of neonatal calves. Cedar Rapids, IA: Diamond V Mills. https://www.extension.umn.edu/agriculture/ dairy/beef/the-role-of-oral-immunoglobulins.pdf

45. Dominguez E, Perez MD, Puyol P, et al. (2001) Specific immunoglobulins in serum of newborn lambs fed with a single dose of colostrum containing anti-peroxidase IgG. Res Vet Sci 70, 275-279.

46. Baumrucker CR \& Bruckmaier RM (2014) Colostrogenesis: IgG1 transcytosis mechanisms. I Mammary Gland Biol Neoplasia 19, 103-117.

47. Ghetie V \& Ward ES (2000) Multiple roles for the major histocompatibility complex class I-related receptor FCRn. Annu Rev Immunol 18, 739-766.

48. Rath T, Kuo TT, Baker K, et al. (2013) The immunologic functions of the neonatal FC receptor for IgG. J Clin Immunol 33, $9-17$

49. Tzaban S, Massol RH, Yen E, et al. (2009) The recycling and transcytotic pathways for IgG transport by FcRn are distinct and display an inherent polarity. J Cell Biol 185, 673-684.

50. Anderson CL, Chaudhury C, Kim J, et al. (2006) Perspective FcRn transports albumin: relevance to immunology and medicine. Trends Immunol 27, 343-348.

51. Junghans R \& Anderson C (1996) The protection receptor for IgG catabolism is the beta2-microglobulin-containing neonatal intestinal transport receptor. Proc Natl Acad Sci U S A 93, 5512-5516.

52. Roopenian DC \& Akilesh S (2007) FcRn: the neonatal FC receptor comes of age. Nat Rev Immunol 7, 715-725.

53. Blum J (2006) Nutritional physiology of neonatal calves. J Anim Physiol Anim Nutr (Berl) 90, 1-11.

54. Underwood EJ \& Suttle NF (1999) Iodine. In The Mineral Nutrition of Livestock, 3rd ed. pp. 343-374 [S Hulbert, editor ]. Oxon: CABI Publishing.

55. Pluske JR, Hampson DJ \& Williams IH (1997) Factors influencing the structure and function of the small intestine in the weaned pig: a review. Livest Prod Sci 51, 215-236.

56. Montagne L, Pluske J \& Hampson D (2003) A review of interactions between dietary fibre and the intestinal mucosa, and their consequences on digestive health in young non-ruminant animals. Anim Feed Sci Technol 108, 95-117.

57. Sangild PT, Fowden AL \& Trahair J (2000) How does the foetal gastrointestinal tract develop in preparation for enteral nutrition after birth? Livest Prod Sci 66, 141-150.

58. Besier R \& Love S (2004) Anthelmintic resistance in sheep nematodes in Australia: the need for new approaches. Anim Prod Sci 43, 1383-1391. 
59. Hoste H \& Torres-Acosta J (2011) Non chemical control of helminths in ruminants: adapting solutions for changing worms in a changing world. Vet Parasitol 180, 144-154.

60. Eysker M, Bakker N, Kooyman FNJ, et al. (2005) The possibilities and limitations of evasive grazing as a control measure for parasitic gastroenteritis in small ruminants in temperate climates. Vet Parasitol 129, 95-104.
61. Beasley A, Kahn L \& Windon R (2012) The influence of reproductive physiology and nutrient supply on the periparturient relaxation of immunity to the gastrointestinal nematode Trichostrongylus colubriformis in Merino ewes. Vet Parasitol 188, 306-324.

62. Greer AW (2008) Trade-offs and benefits: implications of promoting a strong immunity to gastrointestinal parasites in sheep. Parasite Immunol 30, 123-132. 